Vol. 4, No. 1, 2018

Oleksiy Bilous ${ }^{1}$, Bohdan Mahura ${ }^{2}$

${ }^{1}$ Department of Applied Materials Science and Materials Engineering, Lviv Polytechnic National University, 12, S. Bandera Str., Lviv, Ukraine, E-mail: volod_11@ukr.net

${ }^{2}$ Department of Forest Engineering, Ukrainian National Forestry University, 103, General Chuprynka Str., Lviv, Ukraine, E-mail: magbogdan@yahoo.com

\title{
APPLICATION OF WEAR-RESISTANT COATING BY ELECTROSPARK ALLOYING METHOD USING AN EUTECTIC ELECTRODE MATERIAL
}

\author{
Received: March 14, 2018 / Revised: May 22, 2018 / Accepted: June 26, 2018
}

\section{(C) Bilous O., Mahura B., 2018}

Abstract. Analysis of the literature database connected with the usage of an electro-spark alloying (ESA) for tool hardening has been carried out in the article.

Necessity of developing a new tungstenless electrode materials with eutectic structure for improvement of an electro-spark alloying technologies has been proved. Therefore, the structure of a new eutectic Fe-Mn-C-B-Si-Cr-Li alloy system has been developed and manufacturing techniques of an alloying by a sintering method has been offered.

The article presents the scientific data obtained on the modern equipment. Electronic spectroscopy - spectral analysis of an eutectic electrode alloy has been carried out by an electronic spectrometer of JAMP-10S model (JEOL). X-ray phase analysis of the alloy has been carried out on the "Dron-UM1".

Keywords: electro-spark alloying, eutectic alloy, fractography of a break, X-ray phase method, spectral analysis, sintering method.

\section{Introduction}

The analysis of scientific papers devoted to the creation of new electrode materials for an electrospark alloying (ESA) shows that tendency for development of tungstenless electrode materials prevails recently $[1,2,3]$. It is due to the higher cost effectiveness and a possibility of replacement of the deficit tungsten and cobalt. It is confirmed by numerous studies on the production of alloys with eutectic structure [4-5], which are dispersion-hardened alloys with optimum ratio of hardness and plasticity due to the presence of plastic matrix and reinforcing phases in their structure. Correlation of such phases can be purposefully changed, obtaining the receipt of eutectic alloys with the prescribed variety of their properties.

That concerns of coatings wear-resistance, which are applied from such eutectic alloys, and, in particular, by an electro-spark processing, in this case the optimum ranges of alloy elements correlations are also possible, and at the same time of plastic and reinforced phases, which substantially change its wear-resistance.

Justification of the elements choice for alloying of the Fe-Mn-C-B system, their concentration and development of the electrode alloy components composition

The Fe-Mn-C-B system has been chosen as a base material, which allows to obtain carbides and metals borides in a structure that significantly increases hardness, wear-resistances, thermal stability and corrosion resistance [6].

The base of the coating (iron) is the main element which is a part of the cutting tool composition and forms solid solutions, chemical compounds and carbides.

Carbon and boron with iron form the eutectics, as well as high-strength carbides and borides. In addition, they have high enough diffusive penetrating during the saturation process of coating basis and, as 
it was remarked above, they efficiently form solid solutions and compounds. Borides also have high abrasive resistance in comparison with refractory carbides and oxides [7].

A manganese has high properties related with an iron and can easily replace it in the carbides, simultaneously increases the plasticity and their dispersion while maintaining its high durability and thermal stability. It is also a good carbide-forming element.

Manganese contributes to the displacement of $\alpha \rightarrow \gamma$ transformation towards much lower temperatures. At the same time, the velocity of the diffusion processes decreases, which slows down the rate of austenite to martensitic conversion [6].

The analysis of the state diagrams shows [6] that with the purpose of formation an eutectic type coating they must have the followings concentrations of elements (by weight): 86.0-97.4\% of iron; $2.2-13 \%$ of manganese; $0.4-1.5 \%$ of carbon; up to $3.5 \%$ of boron.

Accepting the alloy of $\mathrm{Fe}-\mathrm{Mn}-\mathrm{C}-\mathrm{B}$ for basis in the range of concentrations which the eutectic melting (see above) is at, to it finished mixing such elements, as a chrome and silicium, that allowed substantially to promote the level of mechanical descriptions (hardness, wearproofness) and corrosive firmness.

As known, introduction of silicium, which is included in a solution with iron (to $15 \%$ ), substantially promotes hardness and limit of durability of alloy at high temperatures, and at low - offers resistance corrosion. Also does silicium narrow the limit $\alpha$-solution (more than $3 \%$ ), an alloy up to the temperature of melting feels no phase transformations.

Introduction of chrome from $6 \%$ to $20 \%$ considerably promotes corrosive firmness at to simultaneous influence of mechanical tensions [6].

It should be noted that mixing in refractory admixtures (the temperature of melting of chrome and silicium exceeds $1400{ }^{\circ} \mathrm{C}$ and $1500{ }^{\circ} \mathrm{C}$ respectively) does not result in the increase of temperature of synthesis of coverage, so as there is the partial melting of charge at their receipt, but fusion which appeared muffles the not cut-in particles of powder-like mixture as though a diffusive redistribution is considerably initiating them on all volume of liquid phase $[8,9]$.

A wearproof eutectic alloy was thus developed with the high enough level of physical-mechanical parameters [10], which is used for overcoating on a toolpiece.

For the receipt of the indicated eutectic alloy the following components are used: $\mathrm{\Psi}-20, \mathrm{~B}_{2} \mathrm{O}_{3}, \mathrm{Fe}$ $\mathrm{Mn}, \mathrm{FeCr}, \mathrm{FeSi}$. Therefore harmful admixtures - sulphur, phosphorus appear in his composition, oxygen but other. These harmful admixtures sharply reduce the complex of physical - mechanical properties of the bmaterial, because they take place on borders of grains, and it does material fragile, less plastic. The results of researches assert that there is phosphorus to $0.08 \%$, and sulphurs to $0.09 \%$ in the material.

Consequently, to promote the complex of physical-mechanical properties of material, and with it official properties of toolpiece, such, as longevity, wearproofness, reliability, volume of the taken off shaving, to our opinion, it is possible by introduction to his composition of new element, which would have large bring together to phosphorus, sulphur, oxygen and other components, and would provide cleaning of border of grains from these harmful admixtures.

The analysis of data from the literature shows that one of the most effective elements lithium can come forward in such a role [9]. Mixture in to the alloy of lithium promotes mechanical properties and corrosive firmness, the limit of fluidity and durability, in particular, hardness rises, treatment gets better cutting [11]. Lithium in steels and alloys, having a high cognation to oxygen, sulphur and phosphorus, used for degassing, and also for bundle sulphur and phosphorus $[12,13]$. Introduction of lithium strengthens general desulfuration of alloy, condense a structure near-by grains, purges from phosphorus and excretions of oxide, that the wearproofness promotes in an aggregate.

Thus, the supposition is done, that known and used by us in previous researches $[14,15]$ eutectic alloy of the system Fe-Mn-C-B-Si-Cr for the increase of firmness of cutting instrument at treatment of materials, at alloying his lithium, can give an additional positive effect for firmness of cutting instrument. 
It should be noted that lithium with a groundmass (iron) does not co-operate practically. It follows from information from the literature that lithium does not dissolve in hard iron. Boiling lithium (boiling point $1370{ }^{\circ} \mathrm{C}$ ) eroses the iron, but diffusion of lithium in iron to $1200{ }^{\circ} \mathrm{C}$ is not observed [12].

Similarly lithium co-operates with a carbon which only at a temperature $165{ }^{\circ} \mathrm{C}$ forms an eutectic (at $0.1 \%$ on mass of lithium) [13]. The analysis of diagrams of the state of lithium shows with a chrome and silicium, that a to $5 \%$ (on mass) lithium does not have co-operation both in the liquid (two liquid liquids which are unmixed appear) and in hard state [13].

There is not information about co-operating of manganese with lithium. We know well, that a manganese without restriction dissolves in iron both in the liquid and in hard, state, that's why probability of co-operation of it with lithium absents practically. Boride at co-operating with lithium in proportion 1:6 forms black powder. Research X-ray structural show that powder is mixture of the boron and unidentified boride of lithium [13]. It is therefore impossible to do a certain conclusion neither about his composition nor about his structure.

From what is said above it is possible to draw the conclusion that with basic components which form eutectic material of the system Fe-B-Mn-C-Si-Cr, lithium does not co-operate practically, what can not be said about harmful admixtures which appear in this alloy at his synthesis. At co-operating of lithium with sulphur does the sulfide of lithium $\left(\mathrm{Li}_{2} \mathrm{~S}\right)$ appear at the temperature of melting $975{ }^{\circ} \mathrm{C}$ [13].

Phosphorus with lithium forms two phosphides of $\mathrm{LiP}$ and $\mathrm{Li}_{3} \mathrm{P}$, at what $\mathrm{Li}_{3} \mathrm{P}$ has a hexagonal grate as $\mathrm{Ni}_{3} \mathrm{As}(\mathrm{a}=4.273 \AA, \mathrm{s}=7.594 \AA$ ) [13]. Lithium well co-operates with oxygen, forming oxides. Lio 2 has a face-centered cubic grate as $\mathrm{CaF}_{2}(\mathrm{a}=4.602 \AA) . \mathrm{Li}_{2} \mathrm{O}_{2}$ has a tetragonal grate $(\mathrm{a}=5.49 \AA, \mathrm{s}=7.76 \AA)$ [13].

From literary sources it is evident that lithium links harmful admixtures intensively, that substantially can promote the level of physical - mechanical properties of eutectic material.

\section{Features of the wear-resistant coatings application technology by electro-sparking alloying}

As known, electro-spark treatment of metals, in particular, an electro-spark alloying of metallic surfaces is based on the use of the phenomena which accompany instantaneous liberation of electric energy. This process is characterized the high temperature of incandescence of spark by ionization of interelectrode space.

As at ESA the short at times impulses of electric current flow by duration from $10^{-3}$ to $10^{-5}$ seconds, taking of heat on an electrode from the place of digit to periphery is not provided the heat-conducting of metal and due to it the small volumes of superficial layer are added sharp fluctuations in a temperature from the temperature of boiling of metal of electrode to the temperature in a few ten of degrees.

As a result of it, at first, the change of structure of superficial layer of metal takes place; secondly, the presence of high ionization of interelectrode interval creates necessary terms for flowing on the metallic surface of chemical reactions, which causes the change of composition of superficial layer of metal.

The result of ESA depends on: technological parameters (electric mode and specific time); optimum combination of materials of electrode and processed good; external of the processed good environments; qualifications of operator.

The electric mode, which is determined by the size of energy which is selected in an interelectrode interval, influences on intensity of process of ESA, that is why there is a necessity to manage this size in the operating setting of "Elitron-20". The different modes of treatment, which engulf the considerable range of powers both for realization of "rough", are for this purpose foreseen and high-precision processes of ESA.

Specific time of alloying (time is in minutes, that it is outlaid on treatment of square centimeters of surface) is closely related to the electric modes.

On more powerful modes in the first minutes of work of causing of metal carried out most intensively, transference is slowed consequently, halted. Subsequent work results in destruction of the inflicted layer, and sometimes and to material of the processed good. Thus, remaining time of 
treatment on the powerful and middle modes is not instrumental in causing of new layer, and to destruction of initial surface.

The size of time at which coverage takes place maximum depends on properties of materials which are inflicted and processed. Minimum limit of time of treatment allows to get continuous coverage of all surface, maximum limit results in the decline of transfer of metal on good, a surface very deteriorates as a result, humps appear and temperings.

The different modes of treatment are used depending on requirements to the processing surface, its cleanness, wholeness, thickness and porousity of the inflicted layer, and also to the possible size of transitional area (thermal affected zone which is located under a superficial layer, in which diffusive processes take place). On the minimum modes of treatment, that than less energy of impulses of current, the less is a thickness of layer, got in time unit on unit of surface, but the top quality of the inflicted coverage. The small thickness of transitional area (especially on the tempered materials) takes place in this case, and the inflicted superficial layer is most closeness and his surface is cleaner in all. Very often it follows to give advantages the fixed skims, than to get thick layers which are more porous and more fragile. The maximum modes of treatment (when more energy is selected in every single impulse) result in the transfer of greater portion of material. Mainly the thickness of coverage makes $10-200 \mathrm{mkm}$ with the height of inequalities of type within the limits of $\mathrm{Ra}=2.5-100 \mathrm{mkm}$, by a wholeness more than $80 \%$. Different conductive materials are used as quality electrodes.

The effect of ESA largely depends on external of good environments. During working as a toolpiece which is fixed ESA by a method often intensification of the cutting modes is instrumental in the additional increase of firmness. A not less value for achievement of positive results of application of ESA has qualification of operator. To failings which arise up during unskilled labour, flashing off of cuttings verges, low wholeness and unevenness of coverage, presence of humps, belong and temperings.

Taking into account all said above, as the sequence of works for ESA of cutting instrument and laboratory standards the following flowsheet was accepted (Fig. 1): preparation of surface of the fastened good, direct treatment of ESA of this surface, on the certain modes of technological process, control of quality of the inflicted coverage.

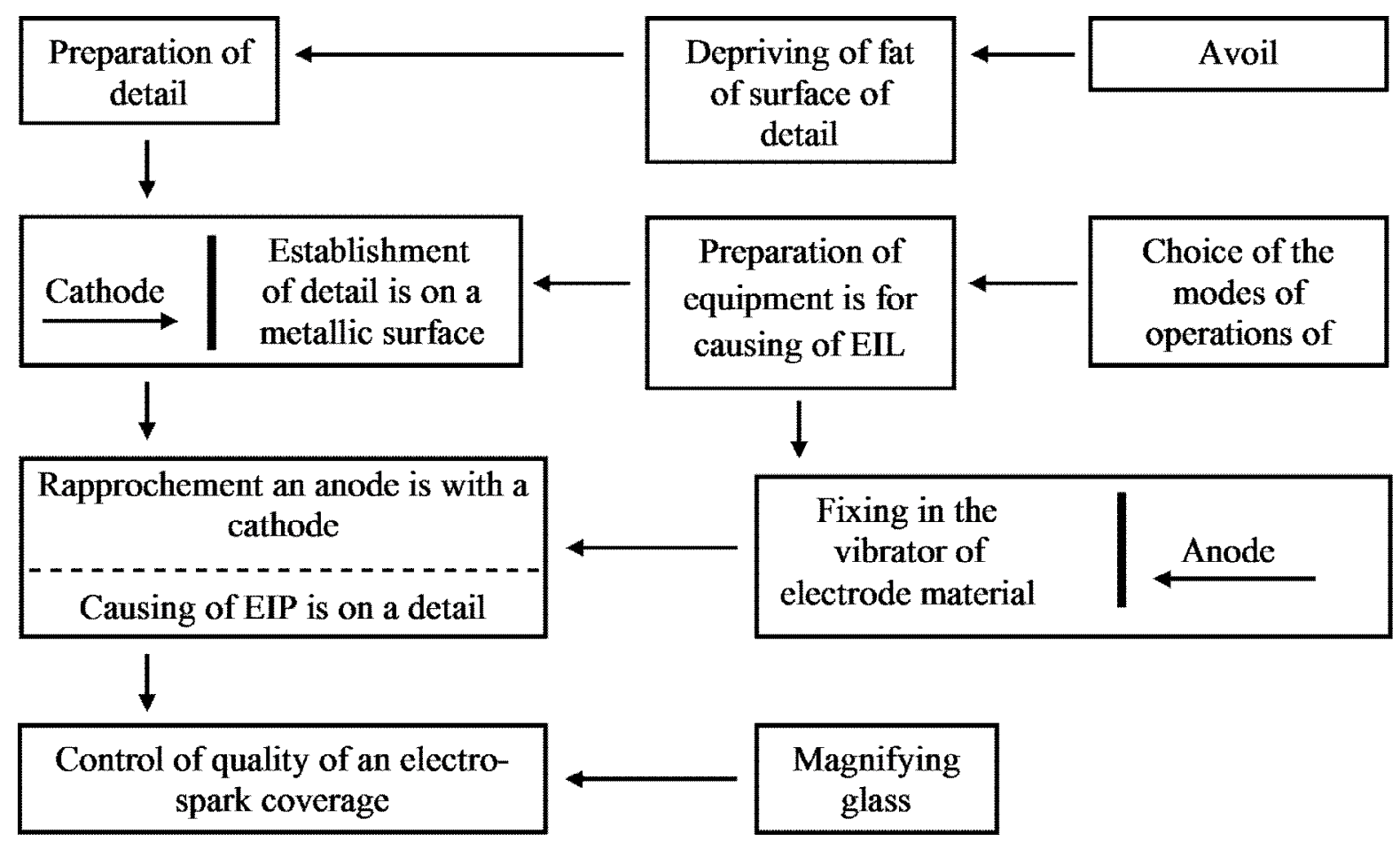

Fig. 1. Technological block-diagram of application the electrospark coating 
Quality of the fixed layer of cutting instrument, especially durability of his tripping with basis, substantially depends on preparation of cutting verge of chisel. The process of preparation of surface is included by two stages: depriving of fat and tooling of surface for overcoating. Depriving of fat carried out in well-known solvents (except for ethyl petrol, to the acetone and others like that). After depriving of fat removed tracks of corrosion, possible dross, other contaminations by polishing and took a surface to metallic brilliance.

As a result of numerous tests of process of ESA by an eutectic electrode on setting of "Elitron-20" with different technological parameters, the most optimum modes of causing of an electro-spark coverage were accepted on the cuttings edges of cutting instrument: capacity of story condensers of $\mathrm{C}=470 \mathrm{mkF}$, amplitude of impulses of tension on the condensers of $U=42 \mathrm{~V}$, working current of Ip $=5 \mathrm{~A}$, energy of high bit of $\mathrm{W}=0.37$ Joule. Such regime parameters are accepted as a result of the detailed analysis of influence of the factors described higher on the process of ESA.

On the cutting instrument of electrospark coverage after the given modes it is accepted the basic stages of technological process of causing: rapprochement an anode (to the electrode) is with a cathode (product); hasp of workpiece-to-electrode; decatenation from to the anode of drop of molten metal; explosion of molten drop; besieging of material an anode is on a cathode; a contact of electrode is with the surface of good; divergence of electrode is with the surface of good.

Control of quality of the inflicted electro-spark coverage was carried out an external review and $4-10 \mathrm{x}$ whether by magnifying glass (ГОСТ 8309-75).

\section{Structure and basic physical and mechanical properties of electrode alloy and wear-resistant electrosparking coating}

Erosive firmness of eutecticum alloys in the process of ESA depends on the row of physical and thermal constants of alloying elements, which characterize force of interatomic connection and inflexibility of crystalline structure of alloy, that those factors which influence on correlation of liquid and hard phases in the products of erosion. Will mark that transference of electrode material at ESA is carried out actually in liquid and hard forms, that promotes descriptions of mass transfer and improves quality of surface. A presence in the structure of eutecticum alloy of fusible eutecticum is predetermined by an increase as compared to the tungsten alloy of erosion an anode and increase a cathode in 2-3 times. The coefficient of transfer is here increased to $93 \%$ [16].

The fractographies of fracture of eutectic electrode alloy are presented in Fig. 2. The fracture of alloy in swingeing majority has viscidly plastic character with the strongly ramified structure of surface.

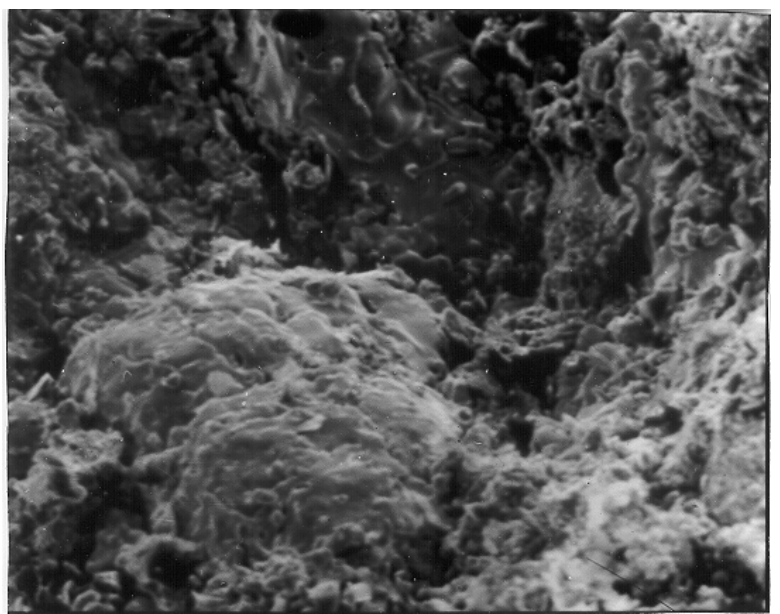

$a$

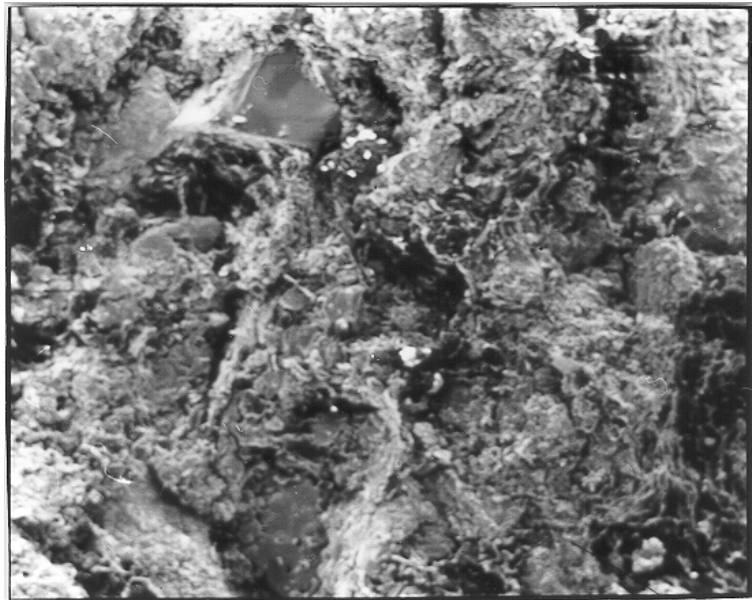

$b$

Fig. 2. Fractographies of an electrode eutectic alloy fracture, $x 300$ (Images in the secondary electrons) 
Specific time of alloying (time is in minutes, that it is outlaid on treatment of square centimetre of surface) is closely related to the electric modes.

On more powerful modes in the first minutes of work of causing of metal carried out most intensively, transference is slowed consequently, halted. Subsequent work results in destruction of the inflicted layer, and sometimes and to material of the processed good. Thus, remaining time of treatment on the powerful and middle modes is not instrumental in causing of new layer, and to destruction of initial surface.

The size of time at which coverage takes place maksimum depends on properties of materials which are inflicted and processed. Minimum limit of time of treatment allows to get continuous coverage of all surface, maximum limit results in the decline of transfer of metal on good, a surface very deteriorates as a result, humps appear and temperings.

Spectroscopy researches of eutectic electrode alloy by the method of electronic spectroscopy rotined a high equitability chemical elements for the areas of particles which was added an analysis. In a spectrum there are all basic chemical elements which enter in the complement of this eutectic alloy. Except for it, high sensuality of method to the easy elements in the high-current mode allowed to fix the presence of lithium in an alloy in very small concentrations.

The standards of electrode alloy as fine-grained conglomerates for providing of reliable output of current pressed in in an indium. The presence of indium in this spectrum is explained to intentional out-offocus the probe of to $50 \mathrm{~nm}$ for determination of content of elements for the surfaces of fracture. A form and size of peaks of oxygen and carbon (as to the antagonist of process of oxidization) allows to think about the low degree of oxidization of surface of fracture.

Study of coarse-fine low power part of spectrum allowed to find out weak lances. This phenomenon can be explained a segregation on-the-spot fracture of elements with high diffusive mobility, such as sulphur and phosphorus. In the resulted spectrum of lance of electrons of iron imposed with high exactness on basic lances of manganese which does uttery difficult their division with the purpose of quantitative analysis.

Complete record of distributing of chemical elements stabilizing of them served as a criterion on the depth of standard. On border of distributing (transitional layer) formation of tape of oxide took place in the process of making of standard.

By a X-ray phase analysis in the standard of electrode alloy found out four phases (Table 1).

Table 1

Crystallogeometrical characteristics of the structural components in the electrode alloy

\begin{tabular}{|c|c|c|c|c|c|}
\hline \multirow{2}{*}{$№$} & \multirow{2}{*}{ Phase } & \multirow{2}{*}{ Spatial group } & \multicolumn{3}{|c|}{ Size of crystalline grate, nm } \\
\cline { 3 - 5 } & & & $\mathrm{a}$ & $\mathrm{b}$ & $\mathrm{c}$ \\
\hline 1 & $\alpha-\mathrm{Fe}$ & $\mathrm{Im} 3 \mathrm{~m}$ & $0,2867(1)$ & - & - \\
\hline 2 & $\mathrm{Fe}_{3}(\mathrm{C}, \mathrm{B})$ & $\mathrm{Pbnm}$ & $0,4572(1)$ & $0,5110(1)$ & $0,6713(1)$ \\
\hline 3 & $\mathrm{Fe}_{2} \mathrm{~B}$ & $\mathrm{I} / \mathrm{mcn}$ & $0,5115(1)$ & - & $0,4249(1)$ \\
\hline 4 & $\mathrm{Fe}_{3}(\mathrm{Si}, \mathrm{B})$ & Pbnm & $0,4468(1)$ & $0,5335(1)$ & $0,6670(3)$ \\
\hline
\end{tabular}

Basic phase $-\alpha-\mathrm{Fe}$ with the period of body-centred cube (BCC) grate $-2.867(1) \AA$. For quantitative composition such phase is register the phase of type of cement carbide with a rhombic grate $-\mathrm{Fe}_{3}(\mathrm{C}, \mathrm{B})$ $(\mathrm{a}=4.572(1) \AA, \mathrm{b}=5.110(1) \AA, \mathrm{c}=6.713(1) \AA)$. Taking into account the difference of the resulted periods of grate in relation to such in clean $\mathrm{Fe}_{3} \mathrm{C}$, it costs to assume that in our case substituted for part of atoms of $\mathrm{Fe}$ other atoms $(\mathrm{Mn}, \mathrm{Cr})$. The third registered phase in a feedstock for an electro-spark alloying was a tetragonal phase of boride iron $-\mathrm{Fe}_{2} \mathrm{~B}(\mathrm{a}=5.115(1) \AA, \mathrm{s}=4.249(1) \AA)$. Other lines (Table 1) which remained on the diffractogram of initial standard, satisfactorily index within the framework of rhombic structure of isomorphic cement carbide, in which substituted for a carbon silicium - $\mathrm{Fe}_{3}(\mathrm{Si}, \mathrm{B})(\mathrm{a}=4.468(1) \AA$, $\mathrm{b}=5.335(1) \AA, \mathrm{s}=6.670(3) \AA)$. It should be noted that there is a two-bit of austenite in a standard, however much all his lances coincide with the strong imprints of other registered phases. 
Thus, as a result of researches of structural constituents of eutectic electrode alloy of the system Fe-Mn-C-B-Si-Cr-Li and it basic physical - mechanical properties it is set that the eutectic of Fe-B-C will be realized in this system. Will mark as chance offers, that the basic system Fe-Mn-C-B has two eutectic areas [6] the eutectic of Fe-Mn-C and Fe-B-C can be realized in which. Therefore given higher in a table. A 1 phase composition of eutectic electrode alloy substantially differs from phase composition of eutectic electrode alloy of the system Fe-Mn-C-B-Si-Cr (is there a presence in the $\alpha-\mathrm{Fe}$ and $\gamma-\mathrm{Fe}$, manganese carbide of iron of $\mathrm{Fe}_{0,4} \mathrm{Mn}_{3,6} \mathrm{C}$ and $\mathrm{Fe}_{3} \mathrm{C}$ ), which was used for causing of ESC during the leadthrough of comparative researches of wearproofness of instrumental steels. Concerning ESC got from the eutectic electrode alloy of the system Fe-Mn-C-B-Si-Cr-Li it should be noted that phase composition of such coverage is adequate phase composition of eutectic electrode alloy, but structurally ESC and in this case has the appearance of "white layer".

The characteristic type of the inflicted electro-spark coverage with the use of eutectic electrode material is rotined the method of ESA in Fig. 3.

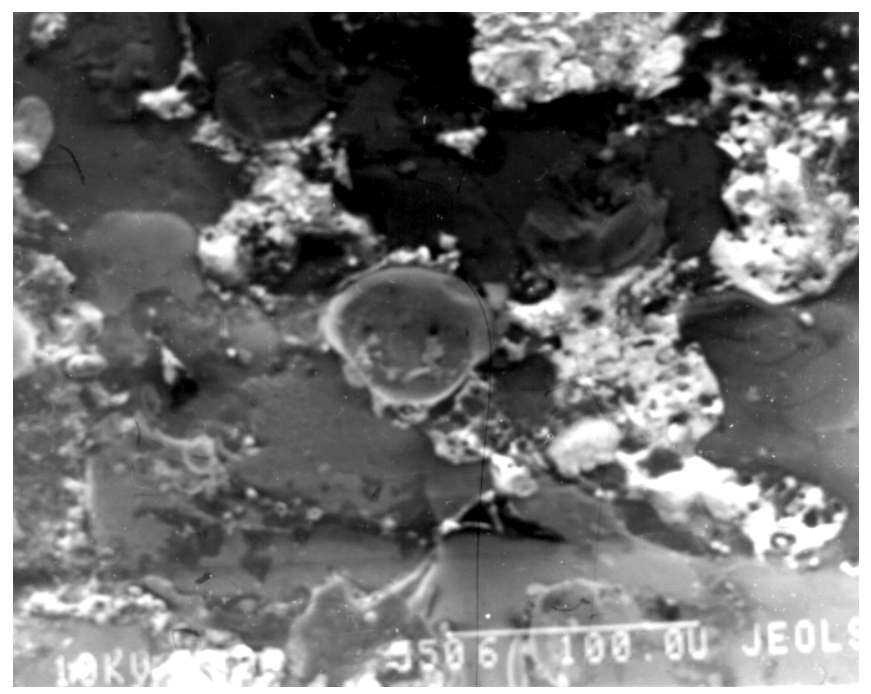

Fig. 3. General view of electrospark coating applied by ESA $(x 70)$

Erosive fossulas which appear under an action on metal ground of high bits take shape, which depends on the diameter of electrode and angle of his slope to the plane of basis. The diameter of fossulas made $0,5-0,8 \mathrm{~mm}$, depth of penetration in basis of $80-120 \mathrm{mkm}$, width of the thermal affected (TIZ) of 70-100 mkm zone. Within the limits of TIZ there is growing of grain shallow under the action of a spark digit. The same, and also by the involuntary extrass of material outside a fossula, the presence of microcracks is explained on the bottom of fossula and them too uneven microrelief.

On the next stage of researches conducted the estimation of tribocharacteristic of an electro-spark coverage (ESC) on the machine of friction of СМЦ - 2, which was carried out at the friction of chisel with a counterbody at different speeds $(6 \mathrm{~m} / \mathrm{s}$ and $9 \mathrm{~m} / \mathrm{s})$ and loading $20 \mathrm{H}$. Time made works 300 seconds. The wearproofness of chisels was estimated after a gravimetric wear by coverages.

Results rotined that maximum values of concentration of elements of the basic system $\mathrm{Fe}-\mathrm{Mn}-\mathrm{C}-\mathrm{B}$ is chosen, coming from possibility of receipt of alloys of eutectic type in obedience to the diagram of the state [6].

Content of additional alloying elements (to the chrome, silicon) is limited possibility of receipt of alloys with an eutectic structure and enhanceable physical - mechanical properties of coverage which is well described in-process [6].

As for the alloying element (lithium), its introduction to composition of material less than $0,3 \%$ is non-productive, because this concentration does not allow fully to remove (to link) harmful admixtures, such as $\mathrm{P}, \mathrm{S}, \mathrm{O}_{2}$, that take place on boundaries of grains. This reduces the effect of introduction of lithium in composition of electrode material. 
Exceeding of maximum value of lithium (1,15\% on mass) also worsens the level of mechanical and operating properties of coverage due to appearance in his structure of free (unconnected) lithium, because it practically does not co-operate with basic alloying elements. It sharply reduces descriptions of durability of alloy and worsens wearproofness of coverage.

Optimum physical - mechanical descriptions of coverage from point of wearproofness take place at the following composition of components of electrode material: $\mathrm{C}-0,8 \% ; \mathrm{Mn}-3,5 \% ; \mathrm{B}-2,55 \% ; \mathrm{Si}-$ $2,78 \% ; \mathrm{Cr}-9,75 \% ; \mathrm{Li}-0,85 \%$; Fe are other; correlation of $\mathrm{B}: \mathrm{Li}$ is $3: 1$. Thus the high values of wearproofness are marked both in the case of application of steel of U8 and to steel of R6M5.

\section{Conclusions}

Among the eutectic alloys which are recommended for coverage by the ESA method, according to their physical-mechanical characteristics, a main place is occupied by materials of the Fe-Mn-C-B system alloyed by the different additions, which increase their hardness, corrosive durability and wear resistance. The disadvantages of indicated systems is the fact, that during the synthesis of these coatings, such harmful impurities as sulfur, oxygen, phosphorus and others, appears in their structure, that significantly reduces the level of service characteristics of the coatings due to their fragility. The introduction of lithium in the composition of such kind of coatings can significantly reduce the negative impact of harmful impurities. From literature data it can be seen that lithium is a good deoxidizer, cleans the structure from phosphorus and increases the desulfurization of the alloy, therefore, its introduction into eutectic alloys can have a positive effect on increasing the stability of the cutting tool.

The technology of obtaining the wear-resistant coating using the method of electro-spark alloying with the application of eutectic electrode materials with lithium admixtures has been proposed. Optimal modes of the technology of applying a wear-resistant electrospark coating on the cutting edges of the cutting tool has been determined.

Investigation of eutectic alloy using the Auger electron spectroscopy method showed a high distribution equitability of chemical elements by the analysed particles surface. In the spectrum there are all the basic chemical elements, that are present in this eutectic alloy. Except for it, the high sensitivity of the method to the light elements in the high-current mode allowed to record the presence of lithium in the alloy at a very low concentrations.

$\mathrm{X}$-ray diffraction analysis of the eutectic alloy showed the presence of phases: $\alpha-\mathrm{Fe}, \mathrm{Fe}_{3}(\mathrm{~B}, \mathrm{C}), \mathrm{Fe}_{2} \mathrm{~B}$, $\mathrm{Fe}_{3}(\mathrm{Si}, \mathrm{B})$. In the study of wear-resistant coating, the maximum of $\mathrm{Fe}_{3} \mathrm{O}_{4}$ oxides has been recorded radiographically, with the exception of the $\alpha-\mathrm{Fe}, \gamma-\mathrm{Fe}$. After the removal of coating surface layer, the peaks of the indicated oxide has not been recorded. There are three phase components on the diffractograms of polished samples: $\alpha-\mathrm{Fe}, \alpha-\mathrm{Fe}$ and $\mathrm{Fe}_{3}(\mathrm{~B}, \mathrm{C})$. And the amount of austenite is about $5 \%$.

\section{References}

[1] A. D. Verkhoturov, et al., "Svoistva iznoso-stoikikh pokrytii iz evtekticheskikh splavov khrom - karbid" ["Properties of wear-resistant coatings from eutectic chromium-carbide alloys"], Poroshkovaia metallurgiia [Powder metallurgy], no. 3, pp. 45-50, 1984. [in Russian].

[2] O. V. Bilous, et al., "Vprovadzhennia suchasnykh tekhnolohii zmitsnennia instrumentalnykh stalei dlia obrobky derevynnykh materialiv" ["Implementation of modern technologies for the strengthening of instrumental steels for the processing of wood materials"], Naukovyi visnyk NLTU Ukrainy [Scientific Bulletin of UNFU], vol. 22.6, pp. 86-90, 2012. [in Ukrainian].

[3] V. M. Golubetc, and M. I. Pashechko, "Printcipy sozdaniia i osobennosti formirovaniia evtekticheskikh pokrytii iz zhidkoi fazy" ["Principles of creation and features of the formation of eutectic coatings from the liquid phase"], Fizyko-khimichna mekhanika materialiv [Physico-Chemical Mechanics of Materials], no, pp. 25-29, 1984. [in Russian].

[4] V. M. Golubetc, Dolgovechnost evtekticheskikh pokrytii v korrozionnykh sredakh [Durability of eutectic coatings in corrosive environments]. Kyiv, Ukraine: Naukova Dumka Publ., 1990. [in Russian].

[5] V. P. Glukhov, Boridnye pokrytiia na zheleze i stali [Boride coatings on iron and steel]. Kyiv, Ukraine: Naukova Dumka Publ., 1970. [in Russian]. 
[6] M. I. Pashechko, V. M. Golubetc, and M. V. Chernetc, Formirovanie $i$ friktcionnaia stoikost evtekticheskikh pokrytii [Formation and frictional resistance of eutectic coatings]. Kyiv, Ukraine: Naukova Dumka Publ., 1993. [in Russian].

[7] M. I. Pashechko, and V. M. Golubetc, "Sposob polucheniia evtekticheskikh termo-diffuzionnonaplavlennykh pokrytii" ["Method for obtaining eutectic thermo-diffusion-deposited coatings"], Metallovedenie $i$ termicheskaia obrabotka metallov [Metallurgy and heat treatment of metals], no. 6, pp. 26-30, 1989. [in Russian].

[8] V. M. Golubetc, and M. I. Pashechko, Iznosostoikost pokrytii iz evtektiki na osnove sistemy $\mathrm{Fe}-\mathrm{Mn}-\mathrm{C}-\mathrm{B}$ [Wear resistance of eutectic coatings based on the Fe-Mn-C-B system]. Kyiv, Ukraine: Naukova Dumka Publ., 1989. [in Russian].

[9] M. V. Maltcev, Metallografiia tugoplavkikh, redkikh i radioaktivnykh metallov i splavov [Metallography of refractory, rare and radioactive metals and alloys]. Moscow, Russia: Metallurgiia Publ., 1971. [in Russian].

[10] V. M. Holubets, and O. V. Bilous, "Trybotekhnichni vlastyvosti zmitsnenykh elektroiskrovoiu i lazernoiu obrobkoiu instrumentalnykh stalei pry tochinni derevynnykh materialiv" ["Tribotechnical properties of hardened electroscope and laser treatment of instrumental steels when finishing wood materials"], Naukovyi visnyk [Scientific Bulletin], vol. 12.2, pp. 107-116, 2002. [in Ukrainian].

[11] V. K. Grishin, et al., Svoistva litiia [Properties of lithium]. Moscow, Russia: Metallurgizdat Publ., 1963. [in Russian].

[12] M. Khansen, and K. Anderko, Struktury dvoinykh splavov [Structures of binary alloys], vol. 2. Moscow, Russia: Metallurgizdat Publ., 1962. [in Russian].

[13] R. P. Elliot, Struktury dvoinykh splavov [Structures of binary alloys]. Moscow, Russia: Metallurgiia Publ., 1970. [in Russian].

[14] O. V. Bilous, et al., "Vplyv vydu nanesenoho pokryttia na trybotekhnichni vlastyvosti rizhuchoho instrumentu" ["Influence of the kind of applied coating on the tribotechnical properties of the cutting tool"], Naukovyi visnyk: Problemy derevoobrobky na rubezhi XXI stolittia: nauka, osvita, tekhnolohii [Scientific Bulletin: Problems of woodworking at the turn of the 21st century: science, education, technologies], vol. 9.5, pp. 239-245, 1999. [in Ukrainian].

[15] O. V. Bilous, et al., "Vplyv rezhymiv rizannia na stiikist instrumentu pry tochinni derevyny" ["Effect of cutting modes on the stability of the tool for finishing wood"], Naukovyi visnyk [Scientific Bulletin], vol. 11.1, pp. 88-89, 2000. [in Ukrainian].

[16] O. B. Hasii, "Rozrobka evtektychnykh elektrodiv dlia elektroiskrovoho zmitsnennia detalei mashyn i osnashchennia" ["Development of eutectic electrodes for electroscrew strengthening of machine parts and equipment"], PhD dissertation, Karpenko Physico-Mechanical institute of the NAS of Ukraine, Lviv, Ukraine, 1993. [in Ukrainian]. 